\title{
Ownership Structure and Dividend Policy of Listed Deposit Money Banks in Nigeria: A Tobit Regression
} Analysis

\author{
Idris Ibrahim \\ Department of Accounting, Faculty of Social and Management Science \\ Kaduna State University, Kaduna, Nigeria \\ E-mail: ibrahimidris53@yahoo.com
}

Hussaini Shuaibu

Department of Accounting, Faculty of Social and Management Sciences

Kaduna State University, Kaduna, Nigeria

E-mail: nasabuwa@gmail.com

Received: December 30, 2015 Accepted: January 07, 2016 Published: April 17, 2016

doi:10.5296/ijafr.v6i1.9277 URL: http://dx.doi.org/10.5296/ijafr.v6i1.9277

\begin{abstract}
Free cash flow hypothesis posit that regular paying of dividend can reduce agency conflict and through this, the range of future probable misuse of resources by management reduces. Ownership structure has been identified to have relationship with dividend policy of a firm. Though the relationship is different for different class of owners and at different level; it does not influence dividend policy uniformly. Although, the linkage between the two has been monitored by many researchers, yet empirical researches do not provide consensus as to the direction of the relationships. Thus, the paper investigates the likelihood impact of ownership structure on dividend policy in the context of agency relation while using managerial ownership, institutional ownership, ownership concentration and foreign ownership on dividend policy in the listed Deposit Money Banks (DMBs) in Nigeria. The research designs are Correlational and ex-post facto using secondary data extracted from the sampled companies' annual financial reports for the period 2010-2014. Maximum likelihood (panel data Tobit regression) is adopted as a technique of analysis for the study, using a sample of ten (10) out of seventeen (17) listed DMBs in Nigeria that served as population. The result shows that managerial ownership and ownership concentration are likely to have significant
\end{abstract}


negative impact on dividend policy of listed DMBsin Nigeria, while institutional ownership is found to have likely significant positive impact on dividend policy of listed DMBs in Nigeria. But foreign ownership is found not to have likely significant impact on dividend policy of listed DMBsin Nigeria. Based on the findings, it is recommended among others those policy makers (Security and Exchange Commission and Corporate Affairs Commission) to design future policies where dividend payment could be facilitated and the diverse range of shareholders to be satisfied most especially minority shareholders. And that a limit should be set for managers on the proportion of shares to be held as this can facilitate dividend payment.

Keywords: Managerial Ownership, Institutional Ownership, Ownership concentration, Foreign Ownership, Dividend Payout Policy

\section{Introduction}

Dividend payment and earnings' retention for business expansion are the two conflicting objectives of an organization. Most of the shareholders are apart from capital appreciation relying on what they will receive (cash) in return for their investment. Regular payment of cash dividend boosts the image of a firm in a capital market because; investors normally give credit to a firm that pays cash dividend regularly. A dividend payout policy and a decision to pay or not to pay dividend during a fiscal year are among the primary element of corporate policy. Firm dividend policy is the financial decision on how much dividend should be paid to the shareholders who will not jeopardize the firms' growth as well as retaining and maintaining shareholders fund and value maximization. The managers are expected to decide on how much of the profit of a company to be distributed (as dividend) and how much to invest (retain) in the form of accumulated profit of a company; or to decide on whether to pay dividend or otherwise. Although paying dividend directly affects the shareholder and firm's ability to use the profit for growth opportunity (Hossein, 2012). The decision to pay or not to pay cash dividend affects both shareholders and firms.

The association of agency cost and dividend policy has been a current development in the corporate finance theory that focused on how dividend payout can be used to control the agency cost of the firm (Syed, Wasim, \& Baqir, 2010). According to Jensen and Meckling (1976), firms pay dividend because of "free cash flow hypothesis" which is based on the notion that there is conflict of interest between managers and shareholders interest (dividend to receive). Managers may decide to allocate the firm resources for their own benefit. As such, this will definitely create agency problems because they may be used to finance negative Net Present Value (NPV) (Thanatawee, 2013). Subsequently, Easterbrook (1984) suggests that firm should return free cash flow to shareholders through payment of dividend. This will reduce the cash that may be squandered by the managers. Dividend mechanism reduces managerial intention to make an over investment decision which will be financed by internal free cash flow (Shehu \& Buba, 2011). Investors prefer to be distributed free cash flows in the form of distributed profit in order to reduce agency costs related to free cash flows. That, according to the agency theory, where there is a conflict between the benefit of manager and shareholders, regular paying of dividend can reduce agency conflict and through this, the 
range of future probable misuse of resources by management reduces (Hossein, 2012).

Evidence from literature suggests that dividend payment can be influenced by different classes of shareholders. But, literature did not provide consensus as to which categories of shareholders facilitate or discourage dividend payment. Although, the linkage between managerial, institutional, concentrated and foreign ownerships with dividend policy has been monitored by many researchers, yet, empirical researches do not provide consensus as to the direction of the relationships.

It is expected that when managers have more control (shares) will tend not to pay dividend regularly or even decides not to pay; preferring instead to retain resources under their control. Dividend payment tend to reduce when the managerial shareholding's voting power increases and getting to zero when they have absolute control (Mehrani, Moradi, \& Eskandar 2011). But the existing literature shows a divergence of opinion on the relationship between managerial shareholdings and dividend payout policy. While some prior studies show that managerial shareholding is negatively associated with dividend payout policy, suggesting that it limit dividend payment. Others indicate that managerial shareholding is not significantly related with dividend payout policy. Therefore, further research is needed to confirm the validity of the findings.

Furthermore, literature suggests that institutional shareholders could provide an effective monitoring role and influence managers to pay dividend. Dividend payment increases with the increasing power of institutional investors. Eckbo and Verma (1994) presumed that institutional investors want free cash flows to be paid to the shareholders in the form of dividend. Therefore, the agency perspective hypothesized a positive relationship between institutional ownership. But prior empirical studies have reported different statistical association between institutional shareholdings and dividend payout policy. Some studies found negative association, some found positive association and others found insignificant association between the two. Therefore, it is not out of place to conduct further research on the area to ascertain position.

Even though, positive association has been predicted on the relationship between ownership concentration and dividend policy, yet there is no consensus on this expectation because of the two conflicting opinions and mix of findings. The first view is that concentration of ownership tends to lower dividend payment because mangers do not face much pressure from many investors. Thus, less profit is distributed in form of cash dividend as a result of ownership concentration because, the shareholding is not much dispersed and consequently less agency conflict exists (Harada \& Nguyen, 2006). Empirically, this assertion is supported by the findings of Gugler and Yutogu (2003), Maury and Pajuste (2002), and Renneboog and Trojanowski (2005). The second opinion is that block investors have enough strength to compel companies to pay dividend in order to reduce agency conflict as well as having powerful seat in the board room to influence management decision to protect their investment (Harada \& Nguyen, 2006; Djankov, 1999). This opinion is empirically supported by the work of Kouki and Guizani (2009), Ramli (2010), Mirzaei (2012). Similarly, it is not out of place to conduct empirical research to also ascertain position. 
Based on the agency theory, foreign investors cannot have direct control over management activities due to distance in geographical location. Therefore, the only way through which they can influence managers is to force them to pay dividend to reduce the level of free cash-flows available to them (Ullah et al., 2012). So, foreign shareholders use dividend pay-out as a tool of disciplinary device, since they cannot directly control their performance. Therefore, a positive association is predicted between foreign ownership and dividend policy.

Prior researches on the relationship between ownership structure and dividend policy has largely focused on companies in the UK and US and other industrialize countries, where the markets and ownerships are widely regulated. In Nigeria, to the best of our knowledge, there is dearth of research works that combine these four variables (managerial ownership, institutional ownership, ownership concentration and foreign ownership) to examine their cumulative impact on dividend policy of listed Deposit Money Banks (DMBs) in Nigeria. Although a study in Nigeria by Adeiza, Kabiru and Muhibudeen (2015) used the four variables in the listed chemical and paints companies, but adopted multiple regression as a technique of data analysis. Mukhtar (2015) also a Nigerian base study applied OLS in determining the statistical impact of ownership structure on dividend payout ratio. In the same vein, Nuraddeed and Hasnah (2015) used pooled OLS to analyze data on ownership structure and dividend policy of conglomerates firms in Nigeria. Similarly, most of the studies on ownership structure and dividend payout policy used standard linear regression model to obtain result and make conclusion. For a study of these nature, where the dependent variable is dividend payout, the right method is maximum likelihood, while the right technique of analysis is Tobit Regression Model (TRM). This is because, dividend payout is a limited dependent variable as it can have only two possible values, i.e. positive value if dividend is paid and zero value if dividend is not paid (but no negative value) as such, the zero values has to be censored in order to have more stable and credible estimate.

Therefore, this paper is based on maximum likelihood (using censored outcome) i.e. to examine the likelihood impact of ownership structure on dividend policy of listed DMBs in Nigeria. The question still remains whether there is any significant relationship between Managerial ownership, Institutional ownership, ownership concentration, foreign ownership and dividend policy of listed DMBs in Nigeria and how do they affect the banks dividend policy?

The aim of this paper is to investigate the likely impact of ownership structure on dividend policy of listed DMBs in Nigeria. The specific objective is to:

i. Investigate whether Managerial ownership (MO)is likely to have significant impact on dividend policy of listed DMBsin Nigeria.

ii. To determine if Institutional ownership (IS) is likely to have significant impact on dividend policy of listed DMBs in Nigerian.

iii. To determine if there is likelihood significant impact of Ownership concentration (OC) on dividend policy of listed DMBs in Nigeria.

iv. To determine if there is likelihood significant impact of foreign ownership (FO) on 
dividend policy of listed DMBs in Nigeria.

Therefore, the study hypothesized in null form as follows:

$\mathrm{H}_{01}$ : MO does not likely have significant impact on dividend policy of listed DMBs in Nigeria.

$\mathrm{H}_{02}$ : IS does not likely have significant impact on dividend policy of listed DMBs in Nigeria.

$\mathrm{Ho}_{3}$ : OC does not likely have significant effect on dividend policy of listed DMBs in Nigeria.

$\mathrm{Ho}_{4}$ : FO does not likely have significant impact on dividend policy of listed DMBs in Nigeria.

The finding of this research is expected to be helpful to potential investors for predicting firms' dividend payment and consequently, valuation of their stock. It will serve as an additional literature and basis of validating theory. The policy implication of the finding will be of great contribution to regulatory agencies like SEC as well CAC

The remaining parts of the paper are organized as follows: section 2: literature review; section 3: methodology; section 4: discussion of results and, section 5: is conclusions and recommendations.

\section{Literature Review}

Firm dividend policy is the financial decision on how much dividend should be paid to the shareholders which will not jeopardize with the firms' growth as well as retaining and maintaining shareholders fund and value maximization. It also encompasses managerial decision of whether to pay dividend or not, by consideration its cash flow, profit and other business opportunities. According to Sharif, Salehi, and Bahadori (2010) firms are generally free to select the level of dividend they wish to pay to holders of ordinary shares, although factors such as legal requirements, debt covenants and the availability of cash resources impose some limitations on this action. According to Kumar (2003), ownership is one of the important variables which influence the dividend payout policies. Though the relationship is different for different class of owners and at different level; suggest that the ownership structure does not influence dividend payout uniformly. The impact changes over the change in size of the holding as well as their identity. Laporta, Lo'pez-de-silanes, Shleifer, and Vishny (2000) studied the dividend policies of over 400 firms from 33 countries around the world, it is found that dividend policies vary across legal regimes in way that is consistent with the idea that dividend payment is the outcome of the effective pressure by monitoring shareholders to limit agency behavior.

\subsection{Managerial Ownership and Dividend Policy}

Nuraddeen and Hasnah (2015) studied the impact of ownership structure and dividend policy of eight listed conglomerates firms in Nigeria for the period 2001-2010 and found a negative relationship between managerial ownership and dividend policy. Kabiru, Adeiza, and Muhibudeen (2015) in their study on corporate shareholding and dividend payout ratio of chemical and paints companies listed in Nigeria for the period 2008-2013, found a significant 
negative impact of managerial shareholding on dividend payout ratio. Shah, Ullah, and Hasnain (2010), studied that relation between ownership and divided policy of Karachi stock exchange. Data of the companies was obtained for the period of 2002 to 2006. They measured ownership structure as percentage of shares held by directors (only). The result shows that there is a positive and significant relationship of ownership structure and dividend policy. He stressed that this reduces the agency conflict and developed the trust of the outsiders and shareholders of the company. He concluded that in developed market where ownership is highly varying, the market power may force the management to distribute dividends and to meet the demand of the investors. Mirzae (2012), in his research, survey of the relationship between ownership structure and dividend policy of Tehran stock exchange found insignificant relationship between managerial ownership and dividend policy. Ullah, Fida, and Khan (2012) investigated the determinants of the corporate dividend policy in the context of agency relationship by selecting 70 during the period 2003-2010. The study found a negative relationship between managerial ownership and dividend policy using both partial and full adjustment models. Sehrish and Afzal (2010) applied OLS, Logit and Probit regression and found that insiders' ownership (management ownership) and profitability show significant negative impact on dividend payment. While the result of logit and probit model show that individual ownership and insider ownership are negatively related with dividend policy but, profitability is positively significant relates to with dividend structure. Agrawal and Jayarawen (1994) and Rozeff (1982) extensively examine the association between the managerial ownership and dividend policy, evidence show that companies pay lower dividend when the managerial shareholding in companies is relatively high. Short, Zhang, and Keasey (2002) did not find evidence in support of the hypothesis that a negative association exists between dividend payout policy and managerial ownership for the UK companies. Strouraitis and $\mathrm{Wu}$ (2004) found that the impact of managerial ownership on dividend yield is positive particularly of the low growth firm in Japan. Kumar (2003) found that corporate and directors' ownership is positive and related in level with dividend policy.

\subsection{Institutional Ownership and Dividend Policy}

Dividend serves a mechanism used to compensate shareholders' for contributing to the asset of a company. Institutional shareholders like banks, insurance companies, trustee funds and investment companies hold peoples' money in trust to utilize it into profitable ventures. Therefore, they are expected to facilitate dividend payment in order to meet investors' expectation. But divergent of opinion and empirical findings make the assertion inconclusive. A study by Nuraddeen and Hasnah (2015) on impact of ownership structure and dividend policy of eight listed conglomerates firms in Nigeria for the period 2001-2010 showed a positive relationship between institutional ownership and dividend policy. Adeiza et al. (2015) also found a significant positive impact of institutional shareholding on dividend payout ratio in chemical paints companies listed in Nigeria.

Thanatawee (2013) examines the relationship between ownership structure and dividend policy in Thailand. The result shows that firm with high ownership concentration and an institution compared with an individual is more likely to pay dividend. Short, Zhang \& Keasey (2002) examine the potential association between ownership structures and dividend 
policy for the UK companies and the results showed strong support for the hypothesis that a positive association exists between dividend payout policy and institutional ownership. Shariff, Salehi, and Bahadori (2010), analyzed the influence of shareholders' ownership on payout ratio. They found a significant positive correlation between institutional ownership and payout ratio. Ullah, Fida, and Khan (2012) also found a positive relationship between institutional shareholder and dividend policy. But, Mehrani, Moradi, and Eskandor (2011) found that there is negative relationship between institutional shareholders and dividend policy. Also Kumar (2003) and Mirzae (2012) further found that institutional ownership has inverse relationship with dividend payout policy. In addition, Azzam (2010) also found that private institutional ownership has negative impact on dividend payout ratio. Bichara (2008) investigated the relationship between institutional ownership and dividend policy where he found that institutional holders only respond positively to dividend initiatives announcement as they adjust their portfolio by buying or increasing their holdings of the dividend paying stock following the announcement. On the other hand, Abdullah, Ahmad, and Roslan (2012) have not found a significant relationship between institutional ownership and dividend policy in Malaysian companies based on Lintner model. Wallgren (2006) investigate whether ownership structure has linkage with dividend policy in Swedish firm and found that institutions does not seem to have any significant effect on dividend level

\subsection{Ownership Concentration and Dividend Policy}

Literature provides two conflicting view. The first view is that concentration of ownership tends to lower dividend payment because mangers do not face much pressure from too much investor. Thus, less profit is distributed in form of cash dividend as a result of ownership concentration because, the shareholding is not much dispersed and consequently less agency conflict exists (Harada \& Nguyen, 2006). Empirically, this assertion is supported by the findings of Gugler \& Yutogu (2003), Maury \& Pajuste (2002) and Renneboog \& Trojanowski (2005). The second opinion is that block investors have enough strength to compel companies to pay dividend in order to reduce agency conflict as well as having powerful seat in the board room to influence management decision to protect their investment. This opinion is empirically supported by the works of Kouki \& Guizani (2009), Ramli (2010), Mirzaei (2012). Similarly, it is not out of place to conduct empirical research to also ascertain position.

To elaborate, Nuraddeen and Hasnah (2015) studied the impact of ownership structure and dividend policy of eight listed conglomerates firms in Nigeria for the period 2001-2010 and found a positive relationship between block-holders and dividend policy. Mirzae (2012), in his research, survey of the relationship between ownership structure and dividend policy of companies listed on Tehran stock exchange by taken 88 sample. He found a positive relationship between ownership concentration and dividend policy. Thanatawee (2013) examines the relationship between ownership structure and dividend policy in Thailand. The result shows that firm with high ownership concentration and an institution compared with an individual is more likely to pay dividends. Mehrani, Moradi, and Eskandor (2011) found that concentrated institutional ownership has positive impact on dividend policy. Wallgren (2006) investigate whether ownership structure has linkage with dividend policy in Swedish firm and 
empirically found that controlling shareholders does not seem to have any significant effect on dividend level. That the votes of largest shareholders are not related to dividend levels but significantly positively related to the propensity to pay dividend. Kouki and Guizani (2009) found a positive relationship between ownership concentration and dividend payout policy among Tunisian companies and that they tend to pay dividend with an increasing power of shareholding by block owners. Gugler and Yutoglu (2003) showed that firms with high ownership concentration tend to pay lower dividends. Also, Maury \& Pajuste (2002) found a significant negative relationship between concentrated institutional ownership and dividend payments among Finland companies. Adeiza et al. (2015) did not find significant impact of block shareholding on dividend payout ratio in chemical paints companies listed in Nigeria.

\subsection{Foreign Ownership and Dividend Policy}

Based on the agency theory, foreign investors cannot have direct control over management activities due to distance in geographical location. Therefore, the only way through which they can influence managers is to force them to pay dividend to reduce the level of free cash-flows available to them (Ullah et al., 2012). This will control them from squandering the money. Adeiza et al. (2015) found a significant positive impact of foreign shareholding on dividend payout ratio in chemical paints companies listed in Nigeria. Lina, Suzan, Ola, and Imad (2012) investigated the effect of ownership structure on dividend pay-out policy of Jordanian industrial public companies for the period 2005-2007. The statistical result consistently supports a significant positive impact of foreign ownership on dividend pay-outpolicy. Ullah et al. (2012) investigated the determinants of corporate dividend policy in the context of agency relation using seventy firms from Karachi Stock Exchange KSE-100 index for the period 2003 to 2010. Stepwise multiple regressions has been used to analyze the influence of ownership structure on dividend payouts. The results showed a significant positive relationship between foreign share ownership and dividend pay-out. This will lead to less availability of the cash flows with the opportunities managers to expropriate the shareholders' wealth, as suggested by the authors. Soojung, Wonsik, and Shin (2010) examined the influence of foreign investors on corporate dividend policy in the Korean stock market. Using sample firms whose ownership by foreign investors was 5\% or higher for the period 2001-2007. The study found that foreign institutional investors with more than 5\% of a company's shares can exert a significant impact on dividends. That is a positive relationship is observed. Minimo and Makesh (2013) examined the impact of foreign institutional investors on corporate dividend policy in Indian firms whose ownership by foreign investors was five per cent or higher for the period from 2007-2011. The study found that foreign institutional investors with more than five per cent ownership do not have a significant impact on corporate dividends. Warred et al. (2012), studied the effect of ownership structure on dividend payout policy in Jordanian context by examining all the industrial companies listed in the Airman stock exchange. The result of his research shows that there is no relationship between foreign ownership and dividend payout policy. Abdullah et al. (2012) studied the influence of ownership structure on dividend policy in Malaysian companies based on Lintner model. They found an insignificant relationship between foreign ownership and dividends. 


\section{Mll Macrothink}

International Journal of Accounting and Financial Reporting

ISSN 2162-3082

2016, Vol. 6, No. 1

The theory that underpins the study this free cash flow hypothesis, an extension of "agency cost theory. It has been argued that agency cost arises because of conflicting interests of the managers and owners. Short, Zhang, and Keasey (2002) argue that dividend policy performs crucial role in reducing agency cost where it may arise because of different interest the parties have. As such dividend payment can be use as mechanism to reduce conflict i.e. to reduce agency cost. According to Jensen and Meckling (1976), and Jensen (1986), dividend may limit insider dissipation by compelling the manager to face the discipline of the market when raising investment funds that would otherwise be freely available in the form of retained earnings. Agency theory also suggests that dividends can be used as a corporate governance mechanism to mitigate agency concern based on the free cash flow hypotheses. Jensen (1986) defines free cash flow as cash flow left after firm has invested all available positive Net Present Value (NPN) projects. He suggests that high payment of dividend could limit the cash availability for managers. Therefore, manager's investment in uneconomic projects or wastage can be minimized. Jensen 1986 and Rozeff (1982) argued that the firm to alleviate the agency problems could use dividend payout policy. Stouraitis and Wu (2004) suggested that the dividend could be used to squeeze the over investment problems of corporation.

\section{Methodology}

The study adopted correlational and ex-post facto design using secondary sources of data. The population of the study is 17DMBslisted in the Nigeria stock exchange as at $31^{\text {st }}$ December, 2014. The data for the study was from secondary source, extracted from the companies' annual reports and accounts covering the period 2010 to 2014. Ten (10) banks were selected as sample of the study considering the fact that they have complete information required for the study.

The dependent variable is dividend policy, proxy by 'dividend pay-out ratio'. While, the independent variable is ownership structure proxy by managerial ownership, institutional ownership, ownership concentration and foreign ownership. Earnings Per Share (EPS) is used to control for firms' profitability. Therefore, a positive relationship between EPS and dividend payout is predicted.

Panel data tobit regression was used as a technique of data analysis. The choice of Tobit regression is because we have limited dependent variable that can have only two possible values (i.e. zero values, if dividend is not paid and positive values, if dividend is paid). For that, estimation that would be obtained from classical regression model will be biased. As such, zero values have to be censored in order to obtain credible result. The tool of analysis was STATA 13.0.

The model of the study is as follows:

$\mathrm{DP}_{\mathrm{RATIOit}}=\beta_{0}+\beta_{1} \mathrm{MO}_{\mathrm{it}}+\beta_{2} \mathrm{IS} \mathrm{S}_{\mathrm{it}}+\beta_{3} \mathrm{OC}+\beta_{4} \mathrm{FO}+\beta_{5} \mathrm{EPSit}+\varepsilon_{\mathrm{it}}$

Table 1. Variable Definition and Measurement

\begin{tabular}{|l|l|l}
\hline Variable & Definition & Measurement
\end{tabular}




\begin{tabular}{|l|l|l|}
\hline \multicolumn{2}{|l|}{ Dependent variables } \\
\hline DP RATIO $_{\text {Independent variables }}$ Dividend pay-out ratio & $\begin{array}{l}\text { Cash dividend paid/number of ordinary share issued } \\
\text { and fully paid }\end{array}$ \\
\hline MO & Managerial ownership & Proportion ofshares held by managers \\
\hline IS & Institutional ownership & Proportion of shares owned by institutions \\
\hline OC & $\begin{array}{l}\text { Ownership } \\
\text { concentration }\end{array}$ & $\begin{array}{l}\text { Proportion of shares owned by an investor or group of } \\
\text { investors from 5\% and above }\end{array}$ \\
\hline FO & Foreign ownership & Proportion of shares owned by foreign investors. \\
\hline Control variable & Earnings per share & $\begin{array}{l}\text { Net profit available to shareholders/ number of } \\
\text { ordinary share issued and fully paid. }\end{array}$ \\
\hline$\beta_{0}-\beta_{2}$ & Beta coefficient & Coefficient of independent variables \\
\hline EPS & Entercept & Constant \\
\hline
\end{tabular}

Source: Compiled by the authors.

\section{Discussion of Results}

This section deals with the presentation and analysis of data collected and processed for the purpose of testing empirically the model of the study. Tobit regression model was used to estimate the likely impact of explanatory variables (managerial ownership, institutional ownership, ownership concentration, foreign ownership and earnings per share) on the dependent variable (dividend payout ratio).

\subsection{Descriptive Statistics}

Table 2. Summary of descriptive statistics 


\begin{tabular}{|l|l|l|l|l|l|}
\hline Variables & observations & Mean & Minimum & Maximum & Std. Dev. \\
\hline DP RATIO & 50 & 0.3396 & 0.0000 & 1.7000 & 0.4783 \\
\hline MO & 50 & 0.0104 & 0.0000 & 0.0416 & 0.0107 \\
\hline IS & 50 & 0.1511 & 0.0000 & 0.4825 & 0.1247 \\
\hline OC & 50 & 0.4067 & 0.0000 & 0.8525 & 0.2461 \\
\hline FO & 50 & 0.1069 & 0.0000 & 0.6030 & 0.1178 \\
\hline EPS & 50 & 0.3972 & -13.57 & 8.7400 & 2.5728 \\
\hline
\end{tabular}

Source: STATA 11.0 output.

Table 2 shows that the mean dividend payoutratio of the banks is approximately 34 kobo per share, while the minimum and maximum are 0 and N1.07Kper share respectively. The maximum value is an indication that some banks paid up to N1.07 from their current or retained earnings to shareholders in form of cash dividend per share within the period 2010-2014. The minimum value (0) shows that some banks did not pay dividend at all during the period. The descriptive statistics further shows that managerial ownership has a mean value of 0.0104 , and minimum and maximum values of 0.000 and 0.0416 . This shows that averagely, the managers of the sampled banks owned $1 \%$ ordinary shares during the period. The minimum value indicates that some bank(s) managers did not hold shares during the period, while some held up to about $4 \%$. The average shares held by institutions is $15 \%$; while the minimum shareholding ranges from the minimum of 0 to a maximum of $48 \%$. This indicates that some banks did not have institutional shareholdings in a particular year(s) within the period 2010-2014. In addition, Ownership concentration has a mean value of 0.4067 , and the range is from the minimum of 0.0000 to a maximum of 0.8525 . This shows that DMBs in Nigeria are mostly owned by individual persons or firms. The mean value for foreign shareholding is $38 \%$, while the minimum and maximum values are $0 \%$ and $60 \%$ respectively; indicating that some banks did not have foreign shareholding while some have up to $60 \%$ foreign shareholding within the period under review. Moreover, EPS has a mean value 0.3972 and the minimum and maximum values stood at -13.57 and 8.74 respectively. This shows that averagely, the banks EPS is 40 kobo per share. The minimum value indicates loss of earnings to the tune of N13.57 per share by some/a bank(s), while the maximum value indicates profit to the tune of $\mathrm{N} 8.74$ per ordinary share.

Table 2 further shows that DPR which is the dependent variable has the highest standard deviation, suggesting high dispersion away from the mean. This is for the fact that DPR assumes only two possible values i.e. zero and positive values. Secondly, the level of 
dividend payout ratio largely depends on bank' size, and earnings. Standard deviation for IS, OC and EPS are all below their respective mean values, suggesting normality of the data since they centered on the mean values. Furthermore, MS and FO have standard deviation slightly above their respective mean values (See appendix).

\subsection{Correlation Matrix}

The correlation matrix is used to determine the degree of association between all the variables of the study. It displays an association be it positive or negative between the regressors and regressand; and it is also use to detect the possibility of multicollinearity.

Table 3. Correlation matrix for the sample observed

\begin{tabular}{|l|l|l|l|l|l|l|}
\hline Variables & DP RATIO & MO & IS & OC & FO & EPS \\
\hline DP RATIO & 1.0000 & & & & & \\
\hline MO & -0.3088 & 1.0000 & & & & \\
\hline IS & 0.2232 & -0.0014 & 1.0000 & & & \\
\hline OC & -2.2158 & 0.1372 & -0.2021 & 1.0000 & & \\
\hline FO & -0.0165 & 0.0335 & 0.4796 & 0.0568 & 1.0000 & \\
\hline EPS & 0.2488 & -0.1132 & 0.0848 & -0.0513 & -0.0278 & 1.0000 \\
\hline
\end{tabular}

Source: STATA 13.0 output.

Table 3 shows that the relationship between managerial ownership and dividend payout is -0.3088 . This indicates that there is a negative relationship between the managerial ownership and dividend payout at 5\% level of significance. It also suggests that dividend payout can reduce with an increase in the proportion of managerial ownership of listed DMBs in Nigeria. Furthermore, the degree of association between institutional ownership and dividend policy is 0.2232. This indicates that there is a positive association between institutional ownership and dividend payout of listed DMBs in Nigeria. In addition, ownership concentration (OC) and foreign ownership were found to have negative association with dividend payout ratio. While the relationship between EPS and dividend payout proved to be positive association (See Appendix)

The table also shows some level of strong correlation between independent variables themselves, i.e. between FO and IS. This suggests a presence of multicolinearity but, its existence is not enough to pose a problem to our statistical inferences. Furthermore, 
correlation matrix only shows degree of association among the variables of the study. But, to determine the real impact, further analysis was conducted using Tobit regression.

\subsection{The Regression Results}

The results in relation to the likely impact of ownership structure on dividend policy of the listed DMBs in Nigeria are discussed below. Hence the regression result is presented in table 3.

Table 3. Summary of Tobit regression result

\begin{tabular}{|l|l|l|l|}
\hline Variables & Coefficients & Z-values & P-values \\
\hline Constant & 0.4989 & 1.71 & $\mathbf{0 . 0 8 7}$ \\
\hline MO & -28.9913 & -3.23 & $\mathbf{0 . 0 0 1}$ \\
\hline IS & 2.6477 & 2.56 & $\mathbf{0 . 0 1 1}$ \\
\hline OC & -1.5946 & -2.35 & $\mathbf{0 . 0 1 9}$ \\
\hline FO & -0.6906 & -1.15 & $\mathbf{0 . 2 5 0}$ \\
\hline EPS & 0.2314 & 3.56 & $\mathbf{0 . 0 0 0}$ \\
\hline Wald Chi2 & $20.29(\mathbf{0 . 0 0 1 1})$ & & \\
\hline Log Likelihood & -24.525633 & & \\
\hline
\end{tabular}

Source: STATA 13 output.

From Table 3, the z-statistics for MO is -3.23 with a significant value of 0.001 . This revealed that MO is statistically significant at $1 \%$ confidence level. This signifies that MO is likely to have negative impact on dividend policy of listed DMBs in Nigeria at $1 \%$ significance level. The implication of this finding is that payment of dividend is likely to reduce with an increasing voting power of managers of the sampled banks. This finding support the free cash flow hypothesis-an extension of agency cost theory which suggests that dividend decreases with the increasing power of MO. Thus, managers prefer to retain earnings instead of given it to shareholders as a dividend. Therefore, the result provides evidence to reject the null hypothesis of the study which states that MO does not likely have significant impact on dividend policy of the listed DMBs in Nigeria. The finding is in line with those of Adeiza et al. (2015), Ullah, Fida, and Khan (2011), Ramli (2010), Eckbo and Verma (1994), Chen et al 
(2005), Short et al (2002), Jensen (1992), Wen and Gia (2010), and Mehrani, Moradi and Eskandar (2011) and contrary to those of Mizael (2012) and Lingling and Wu (2004).

The study further revealed that institutional ownership is statistically significant at $5 \%$ confidence level. This can be attested from the Z-value of 2.56 and the corresponding probability value of 0.011 . This implies that IO is likely to have significant positive impact on dividend policy of listed DMBs in Nigeria. The implication of this finding is that banks with more number of shares owned by institutions are more likely to pay higher dividend that those with smaller proportion. Eckbo and Verma (1994) presumed that institutional investors want free cash flows to be paid to the shareholders in the form of dividend. Therefore, the finding is in line with the agency perspective, which hypothesized a positive relationship between institutional ownership. Because these institutions are mostly banks, insurance companies, trustee funds and investment companies who hold peoples' money in trust to utilize it into profitable ventures. In addition, the coefficient, 2.6477 suggests that dividend payment is likely to increase by $\mathrm{N} 2.65 \mathrm{~K}$ with an increase of $1 \%$ institutional shareholdings. Therefore, the study rejects the null hypothesis raised in section. The finding further support those of Nuraddeen \&and Hasnah (2015), Adeiza et al. (2015), Thanatawee (2013), Ullah et al. (2012), Shariff et al. (2010) and Short et al. (2002).

The Z-value and coefficient value for ownership concentration (OC) are -2.35 and -1.5946 respectively; while the corresponding p-value is 0.019 . This shows that OC has a likelihood of significant negative impact on dividend policy of listed DMBs in Nigeria at $5 \%$ confidence level. While the coefficient is suggesting that dividend payment tend to reduce by $\mathrm{N} 1.59 \mathrm{k}$ when OC increases by one percent. This shows that the higher the ownership concentration the lower the likely cash dividend that would be paid by the banks. The implication of this finding is that when substantial shareholders (those that have 5\% and above shareholding) have more voting power in a bank, dividend payment reduces. This support the argument put by Harada and Nguyen (2006) that less profit is distributed in form of cash dividend as a result of ownership concentration because, the shareholding is not much dispersed and consequently less agency conflict exists. The management might not face too much pressure from investors. The finding provides evidence to reject the hypothesis which states that ownership concentration has no likely significant impact on dividend policy of listed DMBs in Nigeria. The finding has gotten support from the work of Gugler and Yutogu (2003), Maury and Pajuste (2002) and Renneboog and Trojanowski (2005) but contrary to that of Adeiza et al. (2015).

Nonetheless, the table shows that foreign ownership is likely not to have significant impact on dividend policy of listed DMBs in Nigeria. It suggests that FO does not induce or constrain dividend payment by the banks. This can be confirmed from the Z-value of -1.15 with its corresponding p-value of 0.250 . This provides evidence to fail to reject the null hypothesis which posits that FO is likely not to have significant impact on dividend policy of listed DMBs in Nigeria. The finding of the study is in tandem with those of Minimo and Makesh (2013), Lina et al. (2012) and Abdullah et al. 92012).

EPS was introduced in the model as control variable; and it is the major driver of dividend 
payout ratio. The Z-value of 3.356 and the p-value of 0.000 indicate that EPS is likely to have significant positive impact on dividend payout ratio of listed DMBs in Nigeria at $1 \%$ confidence level. This suggests that profitability is the major determinant of dividend policy. It further suggests that dividend payout is likely to increase by $23 \mathrm{~K}$ when EPS increases by one naira (N1).

The Tobit regression result reveals fitness of the model; This is for the fact that the model revealed a Wald chi-square of 20.29 and a probability value of 0.0011 . The implication of this result is that the cumulative impact of independent variables on the dependent variable is significant at $1 \%$ with a $99 \%$ level of confidence.

\section{Conclusions and Recommendations}

The paper investigates the likelihood impact of ownership structure on dividend policy of DMBs in Nigeria in the context of agency relation (and fee cash flow hypothesis) while using managerial ownership, institutional ownership, ownership concentration, foreign ownership and controlling for the earnings per share. Correlational and ex-post facto research design were adopted by using secondary data. The population of the study is the 17 listed DMBs in Nigeria. The study uses data for ten (10) banks for the period of 5 years ranging from 2010 to 2014. Based on the result generated from Tobit regression model, we come to conclude that managerial ownership and ownership concentration have likelihood of significant negative impact on dividend policy of listed DMBs in Nigeria; while institutional ownership has a likely significant positive impact on dividend policy listed DMBs in Nigeria. But foreign ownership does not have likely significant impact on dividend policy of listed DMBs in Nigeria. And finally, the control variable, EPS was found to be positively and significantly related to dividend policy of listed DMBs in Nigeria.

Based on the findings and conclusions, it is recommended that policy makers (SEC and CAC) to design future policies where dividend payment could be encouraged and the diverse range of shareholders to be satisfied most especially minority shareholders. And that a limit should be set for managers on the proportion of shares to be held, this would prevent them from reluctance to pay dividend. In addition, Central Bank of Nigeria (CBN) should intervene in policies related to block ownership by discouraging too much concentration of ownership in the hand of individual or group (as obtained in the developed economy) so as to make ownership to be wider.

\section{References}

Abdullah, H., Ahmad, Z., \& Roslam, S. (2012). The influence of ownership structure on the firms' dividend policy based on Lintner model. International Review of Business Research Paper, 8(6).

Adeiza, M. K., Kabiru, I. D., \& Muhibudeen, L. (2015). Corporate shareholding structure and dividend payout ratio of listed chemical and paints companies in Nigeria. Applied Finance and Accounting, 1(2).

Afzal, M. \& Sehrish, S. (2010). Ownership structure, board composition and dividend policy 
in Pakistan. COMSATS Institute of Information Technology, Islamabad-Pakistan

Al-Nawaiseh, M. (2013).Dividend policy and ownership structure: an applied study on industrial companies in Amman stock exchange. Journal of Management Research, 5 (2)

Azzam, I. (2010): The impact of institutional shareholders and dividend policy on stock return volatility: evidence from Egypt. International Journal of Business 15(4)

Bichara, L. Z. (2008).Institutional ownership and dividend policy: a framework based on tax clientele, information signaling and agency costs. University of North Texas, U.S.A.

Bradford, W., Chen, C. \& Zhu, (). Ownership structure, control chain and cash dividend: evidence from China. Centre for China finance and Business Research, California state University, U.S.A.

Chen, Z. H. Cheung, Y. Stouraitis A. \& Wong, A. (2005).Ownership concentration, firm performance and dividend policy in Hong-Kong, Pac. Bas. Finance. J., 13

Easterbrook, F. H. (1984). Two agency-cost explanation of dividends. The American Economics Review 74(4)

Eckbo, B. E. \& Verma, S. (1994). Managerial ownership, voting power and cash dividend policy. Journal of Corporate Finance 1, 33-62.

Gharaibeh, M., Zurigat, Z. \& Alharahsheh, K. (2013). The effect of ownership structure on dividend policy in Jordanian companies. Interdisciplinary Journal of Contemporary Research in business.

Gul, F. (1999). Growth opportunities, capital structure and dividend policies in Japan. Journal Corporate Finance, 5: 141-168

Javid, A. \& Ahmad, H. (2010). The ownership structure and dividend payout in Pakistan (evidence from Karachi stock exchange 100 index). International Journal of Business management and Economics Research, 1(1).

Jensen, M. \& Meckling, W. (1976). Theory of the firm: managerial behavior, agency cost and ownership structure. Journal of Finance and Economics.

Jensen, M. (1986). Agency cost of free cash flow, corporate finance and takeover.

Kouki, M. \& Guizani, M. (2009)Corporate governance and dividend policy in Poland. WarsawSchool of Economics, World Economy Research Institute, Poland.

Kumar, J. (2003). Ownership structure and dividend payout policy in India. Indira Ghandi Institute of development Research, India.

LaPorta, R., Lo’ pez-de-Silanes, F., Shleifer, A. \& Vishny R (2000). Agency problems and dividend policies around the world. Journal of Finance, 55: 1-33.

Maury, C. \& Pajuste, A. (2002). Controlling shareholders, agency problems, and dividend policy in Finland.Stockholm School of Economics. 


\section{Macrothink}

International Journal of Accounting and Financial Reporting

ISSN 2162-3082

2016, Vol. 6, No. 1

Mehrani, S., Moradi, M. \& Eskandar, H. (2011). Ownership structure and dividend policy: evidence from Iran.African Journal of Business management, 5(17)

Minimol, M. C. \& Makesh, K. G. (2013). Impact of foreign institutional investors on corporate dividend policy in India. India Journal of Research, 3 (4)

Mirzael, H. (2012). A survey of the relationship between ownership structure and dividend policy in Tehran stock exchange. International Conference on Management, Applied and Social Sciences, Dubai.

Mukhtar, M. B. (2015). Ownership structure and dividend policy: an analysis of consumer goods industry in Nigeria. $17^{\text {th }}$ International Academic Conference, Vienna, $21^{\text {st }}$ June, 2015

Nuraddeen, U. M. \& Hasnah, K. (2015). Ownership structure and dividend policy of conglomerates firms in Nigeria. Academic Journal of Interdisciplinary Studies, 4 (2)

Ramli, M. N. (2010). Ownership structure and dividend policy: evidence from Malaysian companies. International Review of Business Research Papers, 6 (1)

Rozeff, M. (1982). Growth, beta and agency costs as determinants of dividend payout ratio. Journal of Financial Research, 5: 249-259

Shah, S. Z., Ullah, W. \& Hasnain, B. (2010).Impact of ownership structure on dividend policy of firms: evidence from Pakistan. International Conference on E-business, management and Economics, Hong Kong

Sharif, S.J. S., Salehi, M. \& Bahadori, H. (2010).Ownership structure of Iran evidence and payout ratio. Asian Social Sciences, 6 (7)

Shehu, U. H. \& Buba, M. M. (2011). Board characteristics and loan portfolio in Nigerian deposit money bank. Nigerian journal of Accounting Research, ABU-Zaria, Nigeria.

Short, H., Zhang, H., \&Keasey, K. (2002). The link between dividend policy and institutional ownership. Journal of Corporate Finance 8, 105-122.

Soojung, K. Wonsik, S. \& Shin, A. K. (2010). Impact of foreign institutional investors on dividend policy in Korea: a stock market perspective. Journal of Financial Management and Analysis, 23 (1)

Thanatawee, Y. (2013). Ownership structure and dividend policy: evidence from Thailand. International Journal of Economics and Finance, 5 (1)

Truong, T. H. \& Heaney. R. (2005). Largest shareholder and dividend policy around the world. Q. Rev. Econ. Finance, 47: 667-687.

Ullah, H., Fida, S. \& Khan, S. (2012). The impact of ownership structure on dividend policy: evidence from emerging market kse-100, Pakistan. International Journal of Business and Social Sciences, 3 (9)

Wallgren, A. (2006). Dividend policy and ownership structure in Swedish firms. Stockholm School of Economics, Department of Finance. 
Lina, W., Suzan, A, Ola, K. \& Imad, A. (2012). The effect of ownership structure on dividend payout policy: evidence from Jordanian context. International Journal of Economics and Finance, 4 (2)

Wu, L. \& Stouraitis, A. (2004). The impact of ownership structure on the dividend policy of Japanese firms with free cash Problem. AFFI December Meeting

Appendix

su dpr ms is oc fo eps
\begin{tabular}{r|rrrrr} 
Variable & Obs & Mean & Std. Dev. & Min & Max \\
\hline dpr & 50 & .3395742 & .4782555 & 0 & 1.7 \\
ms & 50 & .0103886 & .0106889 & 0 & .0416366 \\
is & 50 & .1511156 & .124715 & 0 & .4825 \\
oc & 50 & .40666 & .2461397 & 0 & .8504 \\
fo & 50 & .1067885 & .1178364 & 0 & .603 \\
\hline eps & 50 & .3972 & 2.572677 & -13.57 & 8.74
\end{tabular}

pwcorr dpr ms is oc fo eps

\begin{tabular}{r|rrrrrr} 
& $\mathrm{dpr}$ & $\mathrm{ms}$ & is & oc & fo & eps \\
\hline dpr & 1.0000 & & & & & \\
ms & -0.3088 & 1.0000 & & & & \\
is & 0.2232 & -0.0014 & 1.0000 & & & \\
oc & -0.2158 & 0.1372 & -0.2021 & 1.0000 & & \\
fo & -0.0165 & 0.0335 & 0.4796 & 0.0568 & 1.0000 & \\
eps & 0.2488 & -0.1132 & 0.0848 & -0.0513 & -0.0278 & 1.0000
\end{tabular}

\begin{tabular}{|c|c|c|c|c|c|c|}
\hline Log likelihood & \multicolumn{3}{|c|}{$=-24.525633$} & \multicolumn{2}{|c|}{ Wald chi2 (5) } & $\begin{array}{lr}= & 20.29 \\
= & 0.0011\end{array}$ \\
\hline dpr & Coef. & Std. Err. & z & $P>|z|$ & [95\% Conf. & Interval] \\
\hline $\mathrm{ms}$ & -28.99129 & 8.986315 & -3.23 & 0.001 & -46.60414 & -11.37843 \\
\hline is & 2.647744 & 1.035707 & 2.56 & 0.011 & .6177955 & 4.677693 \\
\hline oc & -1.594623 & .6773558 & -2.35 & 0.019 & -2.922216 & -.2670301 \\
\hline fo & -.6906195 & .6004627 & -1.15 & 0.250 & -1.867505 & .4862658 \\
\hline eps & .2313629 & .0650123 & 3.56 & 0.000 & .1039411 & .3587846 \\
\hline _cons & .4986343 & .2915877 & 1.71 & 0.087 & -.0728672 & 1.070136 \\
\hline /sigma_u & .4162575 & .1417654 & 2.94 & 0.003 & .1384025 & .6941126 \\
\hline /sigma_e & .3341572 & .0503481 & 6.64 & 0.000 & .2354767 & .4328377 \\
\hline rho & .6081126 & .1860951 & & & .2498568 & .8894761 \\
\hline
\end{tabular}


Breusch-Pagan / Cook-Weisberg test for heteroskedasticity Ho: Constant variance

Variables: fitted values of $\mathrm{dpr}$

$\operatorname{chi2}(1)=3.61$

Prob $>$ chi2 $=0.0575$

. vif

\begin{tabular}{r|rr} 
Variable & VIF & $1 /$ VIF \\
\hline is & 1.41 & 0.709159 \\
fo & 1.35 & 0.741341 \\
oc & 1.10 & 0.911477 \\
ms & 1.03 & 0.968607 \\
eps & 1.03 & 0.974536 \\
\hline Mean VIF & 1.18 &
\end{tabular}

